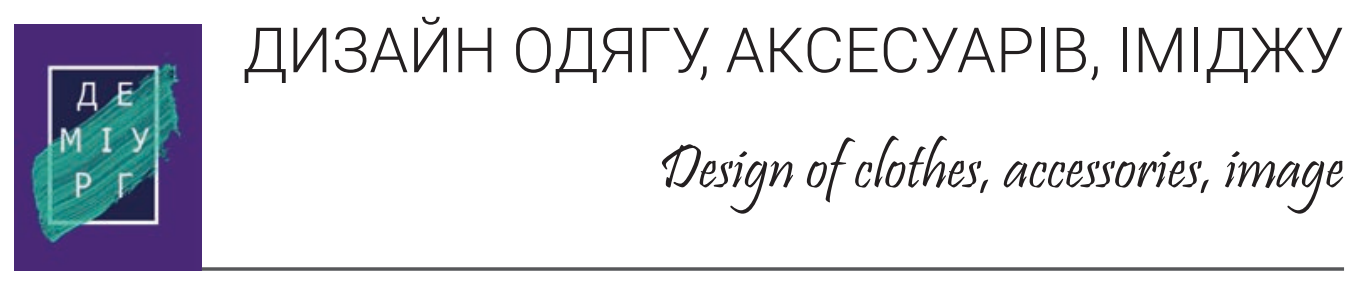

\section{PRINCIPLES OF CLOTHES' TYPOGRAPHIC DECORATION AS A TREND IN MODERN FASHION DESIGN}

Natalia Udris-Borodavko, https://orcid.org/0000-0003-1831-5476 $\mathrm{PhD}$ in Sociological Sciences, Associate Professor at the Graphic Design Department, Kyiv National University of Culture and Arts, Kyiv, Ukraine udris.nata@ukr.com

\section{ПРИНЦИПИ ТИПОГРАФІЧНОГО ДЕКОРУВАННЯ ОДЯГУ ЯК ТРЕНД У СУЧАСНОМУ FASHION-ДИЗАЙНI}

\section{Наталя Удріс-Бородавко,} https://orcid.org/0000-0003-1831-5476

кандидат соціологічних наук, доцент кафедри

графічного дизайну,

Київський національний університет

культури і мистецтв,

Київ, Україна

udris.nata@ukr.com

\section{Abstract}

The aim of the study is to find patterns in the design of typographic compositions for the decoration of clothing, formulate generic recommendations for their design, to study the socio-cultural aspects of this approach in the design of clothing. Research methods. Empirical method, method of analysis, comparison and generalization are applied. Scientific novelty. For the first time, the experience of typographic decor in clothing design 2010-2019 has been generalized in terms of the modernism and postmodernism concepts. The techniques and compositions' artistic features of each type have been systematized. It has been found that in the dichotomy system, "form-content» is typographic elements, where the main purpose is the transmission of content, built largely on a modernist approach; and in the typography, that performs a purely aesthetic function, it is postmodern. It is generalized that a person with the help of clothes decorated with typographic compositions can convey to the environment
Анотація

Мета дослідження полягає у виявленні закономірностей в дизайні типографічних композицій для декорування одягу, формулюванні узагальнених рекомендацій щодо їхнього проектування, дослідженні соціокультурних аспектів такого підходу в дизайні одягу. Методи дослідження. Застосовано емпіричний метод, метод аналізу, порівняння та узагальнення. Наукова новизна. Вперше узагальнено досвід типографічного декору в дизайні одягу 2010-2019рр. з точки зору концепцій модернізму та постмодернізму. Систематизовано прийоми та художні ознаки композицій кожного типу. З'ясовано, що в системі дихотомії «форма зміст» типографічні елементи, де головна мета - передача змісту, побудовані здебільшого за модерністським підходом; а в тій типографіці, що виконує суто естетичну функцію - за постмодерністським. Узагальнено, що людина за допомогою одягу, декорованого типографічними композиціями, може 
the messages of various types. «I am creative» (These are postmodern compositions on the principle of "form"). «I am fashionable» (These are modernist compositions on the principle of «form»). «l am socially active» (These are the most frequent modernist compositions based on the principle of «content», but sometimes there are postmodern solutions). Conclusions. Typographic decor as a trend in modern fashion adds to the clothes of relevance in the context of the information society. A person in a «typographic» outfit not only absorbs information flows. Such an individual himself or herself becomes the source of the communicative space. Clothing with typographic decor is the key to the attention of the environment. It tells about the creativity of the person wearing it, progressiveness, and intelligence, the presence of a public position or a philosophical understanding of life. Such clothes convey the meaning of what motivates and encourages people to communicate directly or indirectly.

\section{Keywords: Ключові слова:}

typography, graphic design, fashion design, modernism, postmodernism, form, content. передавати оточенню повідомлення типів: «я - креативний» (постмодерністські композиції за принципом «форма»), «я - модний» (модерністські композиції за принципом «форма»), «я - соціально активний» (найчастіше модерністські композиції за принципом «зміст», але іноді зустрічаються іпостмодерні рішення). Висновки. Типографічний декор як тренд у сучасній моді додає костюму актуальності в контексті інформаційного суспільства. Людина у «типографічному» вбранні не лише поглинає потоки інформації. Вона сама як об'єкт комунікативного простору стає ії джерелом. Одяг з типографічним декором є запорукою уваги з боку оточення. Він говорить про креативність персони, що його носить, прогресивність, інтелектуальність, наявність громадської позиції або філософського розуміння життя. Такий одяг передає смисли, чим мотивує та закликає людей до прямої чи опосередкованої комунікації.

типографія, графічний дизайн, дизайн одягу, модернізм, постмодернізм, форма, зміст.

Introduction 1

In modern design, there is a convergence of design directions, a comprehensive approach to development, the creation of the objects, which require the interaction of designers of the subject space and visual communications, animation, and fashion industry. This article is about analyzing the interaction of graphic designers and designers of clothing, namely the direction of the use of typographic elements and compositions in the decoration of the components of the suit, which has expanded significantly over the past 5 years. A considerable amount of «typographic clothing» on the streets of cities tells of its widespread use, and therefore typography in clothing has become a fashion trend. The transfer of graphic design products to the field of clothing designers is facilitated by the technological possibilities of computer modeling and digital printing, rapid application of the image to various textiles with a long next use period.

Typography's exit beyond the limits of graphic design in the scale of the fashion trend is of particular attention in the conditions of visual culture domination in the 21st century, which is formed by graphic images, photos, drawings. Increasing interest in verbal elements in the design of different directions, in 
particular fashion, tells about some transformations of common communication processes. Regarding graphic design, we adhere to our hypothesis that in terms of the variability of purely graphic images' interpretations in visual communication products, designers subconsciously seek to add unambiguity to perception by introducing textual phrases as specifying what needs to be conveyed. Thus a designer seems to dictate to the addressee of one or another view of the image, consolidate the meanings and control the interpretation of the images.

Fashion designers strive to find different methods to create not only comfortable but also showy clothes and stay competitive. Therefore, the popularity of typography in graphic design influences their choice and provokes the wish to use in a fashion image not only visual factors (color, tone, shape, proportions of the elements of the product) but also meanings. In addition, typography as a form of decoration allows introducing the naming of the manufacturer's campaign, brand slogans, names, and designers actively. Such background information's presence in the subject environment reinforces their positions in the fashion market and provides hidden advertising communication with the consumer. We consider the clarification of socio-cultural and purely design aspects of the issues outlined in the context of graphic design, clothing and accessories design, and general cultural trends.

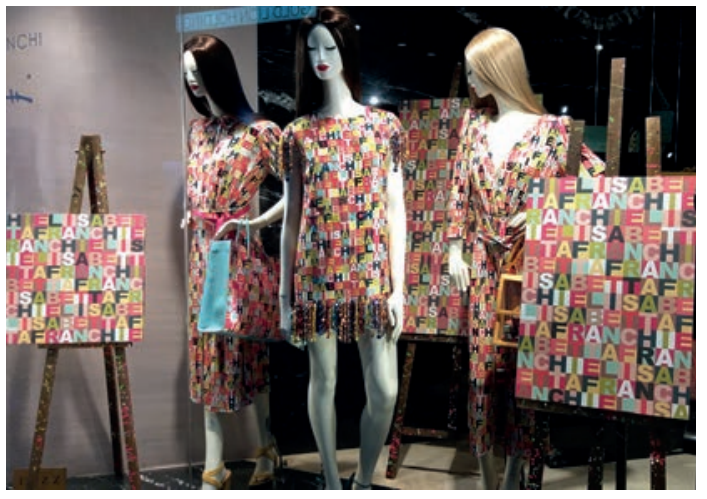

Fig. 1. Showcase of fashion clothing and accessories store. 2019.

Рис. 1. Вітрина модної крамниці одягу та аксесуарів. 2019.

The aim of the study. The aim of this article is to find patterns in the design of typographic compositions for clothes decorating, to formulate generic recommendations for their design, to study the sociocultural aspects of this approach in clothing design. Empirical method, method of analysis, comparison and generalization are applied. This methodological approach allows studying and summarizing techniques and means of typography in the design of clothes, observing their dynamics, analyzing their influence on the sociocultural state in society. 


\section{The methodology and analysis of sources}

For the disclosure of a certain topic, the analysis of scientific works is carried out according to the following vectors: design of typographic compositions in terms of verbal and graphically figurative component, perception of typography on different media, communication and fashion, analytics of fashion collections using typography.

Thus, fundamental research in the field of typography remains the well-known works of E. Ruder and J. Chichold, but the contemporary works of R. Bringhurst (2006) «The Elements of Typographic Style», J. Craig and I.K. Skala (2018) «Designing with Type: The Essential Guide to Typography» are also very significant. They reveal the laws of building fonts, combining fonts with each other, the principles of layout. The effect of font compositions on the viewer is partly considered. The work of French scientist A. Mol «Information Theory and Aesthetic Perception» is the fundamental one in the study of psychophysiology of the verbal and non-verbal messages' perception. We were interested in research by American design scientists K. Knight and J. Glasser, who introduced «visual language» and «verbal language» to avoid misunderstandings. The authors believe that verbal language is the literal meaning of words, phrases and sentences. Typography also refers to «visual language» because in graphic design, «visual language» combines both images and texts, if they are designed based on appearance (Knight \& Glaser, 2012). In fact, anyway, in the design of most typographic compositions, the first choice is precisely the external aspects of the inscriptions.

At the same time, the significance of the content component remains weighty. Ukrainian scientist V. Shevchenko summarizes that «typography as a science studies two aspects of the font: visual (graphics, drawing of letters) and historical (origin of headsets and their use)» (Shevchenko, 2014). In works on purely graphic design, the concept is revealed as «the art of finding the font and components of a polygraphic set in a certain format» (Opaliev \& Savvina, 2014, p. 78), while «good typography» expresses a visual idea and gives it a shape (Ambrose \& Aono-Billson, 2019, p. 121). M. Murashko (2016) draws attention to the fact that the designer perceives the word not just a set of letters. The combination of form, outline, and placement of a word on an artistic plane or screen best conveys and illustrates its meaning. The composition of words formed in a certain way can cause an emotional effect and various impressions (p. 88). As for the imagery of typography messages, we can find a worth mentioning note in the material of journalist and independent analyst A. Batista. She examines the contemporary collection of designers Hokuto Katsui and Nao Yaji through the prism of ideas initiated by the Bauhaus School of Design in the 1920s. Particularly useful in our research is the mention of the motto that Moho Nagy 
called for innovation in the «New Typography» article: «Stop Reading! Look!» (Battista, 2013). In our interpretation, typography is such a visual form of communication in which an artistic image is formed and revealed with the help of a verbal language.

The basic work in discovering the topic of the communicative function of fashion, or more precisely, indirect social communication by means of costume, is, of course, all known to A. Hoffmann's work. Synthesis of other studies of fashion in terms of its place in the social communication system is presented in the article by S. Betz (2014). In particular, it is stated that the communicative function is based on the iconic and symbolic nature of fashion, the presence in it of information carriers about a certain social experience (Bets, 2014). Based on the analysis of philosophical and cultural works on the phenomenon of fashion, $\mathrm{O}$. Shandrenko defines it as «a total setting for communication in the subject and object space of culture» (Shandrenko, 2012). The study of design issues in the context of the sociology of culture has allowed us to advance the author's understanding of the essence of the clothing designer's activity: it visualizes the social role of man, the ultimate purpose of which is interaction (or, rarely, its avoidance), and therefore - social communication.

An example of illustrating the communicative function of fashion as a work of art, in particular a literary work is described in an article by L. Nester (2016), who analyzes G. Keller's novella «Clothing Creates People». Scientists note that clothing is a complex concept and, in addition to its external forms and physical properties, contains cultural and metaphysical meanings. Due to clothing, a person can identify his body, put the contents in the outer shell, express a psychological state. The cultural basis of fashion is that meaningful fullness of a thing is possible not only because of the cultural and intellectual context of the person wearing the thing but also with adequate interpretations by others. "Therefore, we can say that clothing is a complex and independent system of meanings, and the writer, using this system, transmits an encrypted message in his work» (p. 185). A designer, fashion designer, and graphic designer works similarly to the writer. He or she creates a visual code that a person can say something to others, which causes a consumer's choice of clothes.

As a result of the online fashion reviews' analysis, we have come to the conclusion that typography as a garment decor has started to gain popularity again in the collections of the last 5-7 years. For example, they are the projects of Mary Katrantzou, Gianni Versace, Kenzo or the Donna Karan Collection, which promotes the logo of her DKNY campaign with various types of textile decor.

Designer Nadia Papanicolaouou writes about the evolution of such a form of advertising communication by well-known brands 
as the use of their collections of logos in various compositional variants, and emphasizes that as a way of promoting itself this approach has already exhausted its originality. But the development of this wave has become a variety of puns on the theme of wellknown logos such as "Ballinciaga" instead of «Balenciaga» or «Brawlmain» instead of «Balmain», which decorate creative T-shirts (Papanicolaouou, 2013).

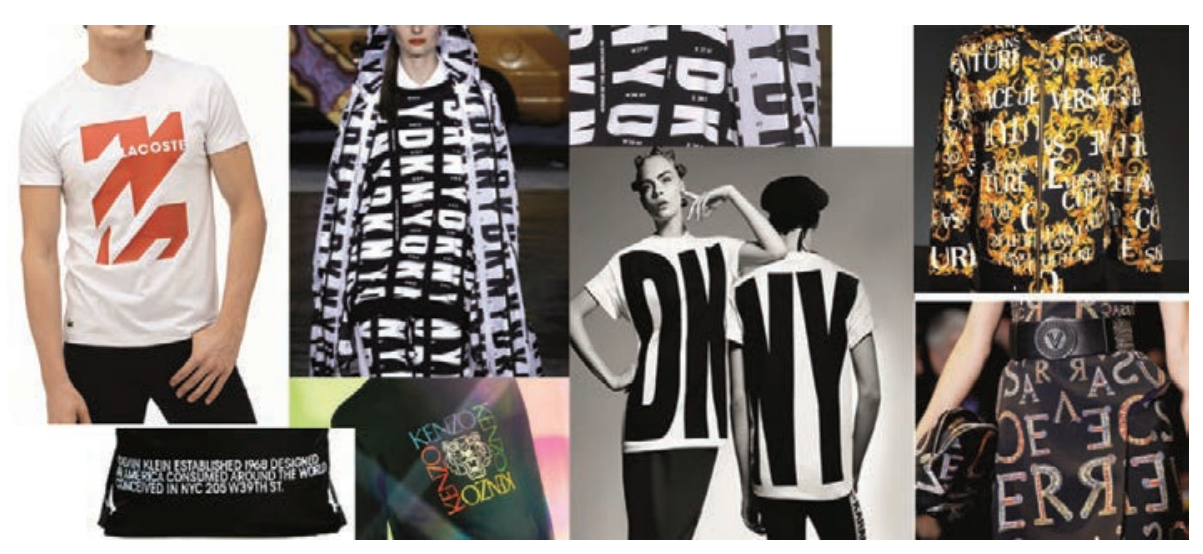

Fig. 2. Fashion products with typographic decoration based on brand logos. Collections of 2012-2019.

Рис. 2. Модна продукція з типографічним декором на основі логотипів брендів. Колекції 2012-2019 рр.

According to daily observations, the move from podiums to the mass use of the idea in everyday products has become a destination (middle-class buyer) in 2018-2019. Today, it has become truly fashionable, that is, widespread and approved by designers and most members of society who use it projects. However, with the high popularity of typographic decor in clothing design, this topic is very limited disclosed in scientific publications. We found an article by a Korean scientist in 2009 (Kim, 2009), whose perception was complicated by hieroglyphics (English abstract only) and two master's studies in design, as well as review publications on thematic sites in small numbers. One of the master's works deals with the psychological aspects of the perception of fonts used in clothing decor. The author states that companies and designers use typography in fashion design to deliver messages and ideas in today's market effectively. In addition, the scientific value of the work is in recommendations creation for designers based on the survey of people about the effects of font effects on the emotions and reactions of recipients (Dahmoos, 2018). In another study, Lamia Skender made a thorough overview of well-known fashion brands in terms of typography in their identity, advertising products, 
fashion magazines, directly in clothing collections, and accessories (Skender, 2015). The work is very interesting, complex, and full of numerous illustrations.

Designer-reviewer Tyler Unger develops an important opinion on the design of typographic elements directly on the pages of an online magazine. He also points out aptly that when looking for a composition, it is necessary for a designer to consider how the typography looks like in a physical space. After all, distances, viewers' perspectives, the perspectives in which the project is perceived - all of these have a bearing on the outcome (Unger, 2017). We consider this a remark to the compulsory testing of typographic compositions in clothes on a person figure, taking into account the various positions and movements before releasing into mass circulation.

So, we can summarize. The theme of the typography application in the garment decoration is very relevant in the practical plane of design. This theme also attracts fashion trendsetters online, as reflected in periodicals. However, the analytics on approaches to the design of typographic compositions in clothing, in addition to analyzing fonts applied, is absent. This proves the relevance of the chosen research topic.

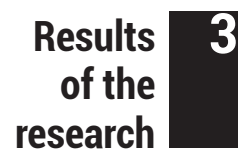

The use of the basic philosophical dichotomy, «form - content», enables us to classify typographic compositions and their application in decorating clothes into several groups.

The first is the group of typographic design, formed on the principle of «form». What is important here is the visual uniqueness of the letters as a graphic element and decoration. Among the utilitarian things with the decor of this type, we find sweaters, shirts, pants, underwear (jackets, coats). It is almost the whole range. In addition, accessories (bags) and shoes are common.

Let us first consider the operation of the text's graphics in fashion design according to the principles of postmodern aesthetics. This is manifested mostly in the use of textile materials, the pattern of which is formed by letters, numbers or punctuation. The composition consists mainly of randomly arranged, approaching each other elements. The selection of characters is usually random in nature, perhaps the single letters of a single word, which, however, are «living their lives» and in some angles can be visually combined.

Postmodern typography, formed by jobbing fonts, grunge structures, asymmetrical compositions, rotation of letters around its own axis in random directions, creates in itself a visual effect of a kind of «whisper», movement on the spot. In some solutions, the use of a counter-form is used when the space into the letters and the space between letters become visual sounding but the letter itself disappears. The use of such a graphic aesthetics on the figure 
of a person, who not only has his or her own relief but also moves enhances the illusion of internal dynamics (Fig. 4.1).
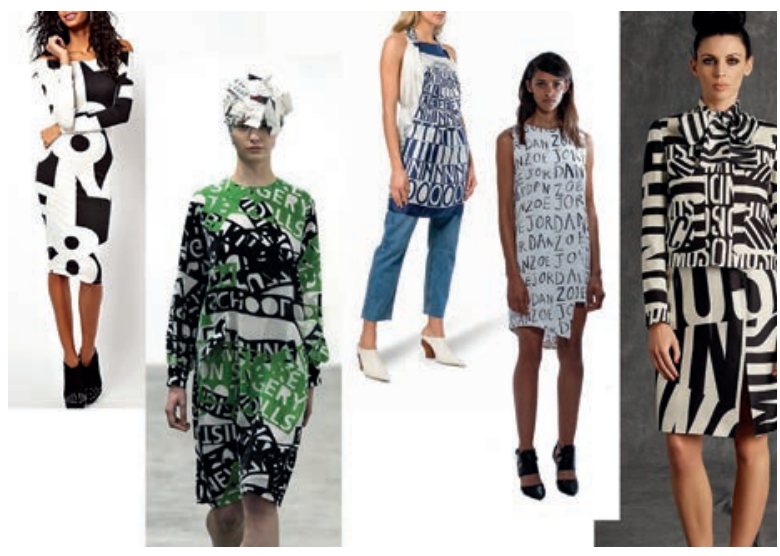

Fig. 4.1. Postmodern concept in typographic decor of clothes. Collections of 2015-2019.

Рис. 4.7. Постмодерністська концепція у типографічному декорі одягу. Колекції 2015-2019 рр.

A hint of certain verbal information, in its real absence compels people from the environment to react to the person in clothing with typographic decor with interest, a desire to unravel used texts and their hidden meanings. The surrounding recipients want to look at the person in such clothing, as their brain seeks to decipher the message placed on the fabric and the suit, even if it is not there.

Postmodern compositions are inherently spontaneous, unique, pluralistic, and creative. These characteristics are also transferred to the clothes wearer with postmodern typography. He allegedly says to the environment, «l am creative!»

To the second method of using typographic decor in the design of clothing, we refer the method, which is based on the principles of modernism. With this concept, the text elements are subordinated to the structure of the product, its cut. Their presence and placement emphasize the composite components of the product. In particular, in the design of the modernist type, the typographic decor is used as sewing ribbons along the seams (for example, stripes on trousers, belts and handles on bags), overhead pockets of various sizes, cuffs. You can also find typographic fragments applied directly to the product by means of printing or embroidery.

In such a modernist application of typography in clothing minimalist bar fonts, are used mostly and the fonts with serifs are used much less often. The compositions use the principle of combinatorics - mainly metric repetitions. Inscriptions of several words or sentences fit into a geometric figure that is subordinate to either the shape of the product itself (such as a bag circle and a pocket rectangle) or a fictitious figure without being tied to the product design, but noticeable on a large, flat plane (such as a long skirt or the back of the shirt). In most cases, a black and white font type solution is 
applied, which is fully consistent with the concept of typography as a component of graphic design. Apparel with a typographic decoration looks quite attractive to the environment and attracts attention, because the letter black and white accents on the monochromatic planes of the product add contrast to its overall tonal decision.

The text displayed on such decor elements usually shows the brand names of the manufacturer, their brand slogans or quotations, which are easy to understand and unambiguous in interpreting the phrase usually positive or neutral emotional color. Kim San Jung writes on this that brands used typography as a commercial tool, for example, to present the image and differentiate the products of one brand from the products of others (Kim, 2009) (Fig. 4.2).

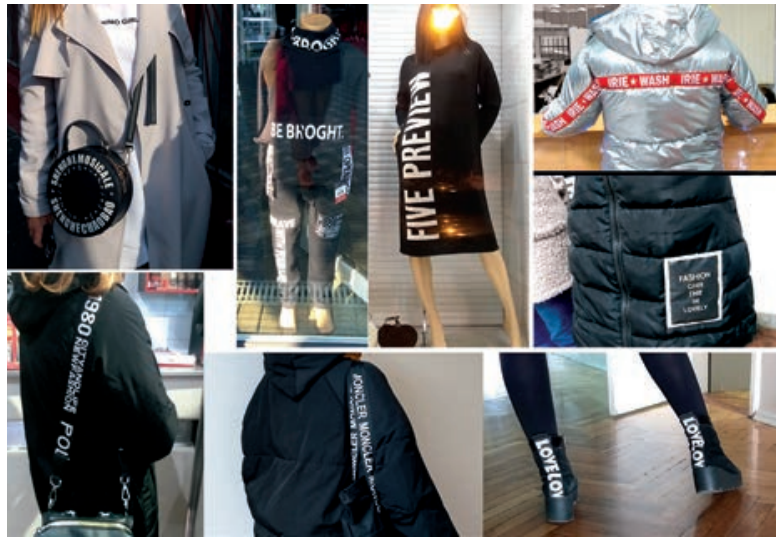

The use of the typographic design in clothing requires the designer to carefully analyze carefully the cultural context of the inscriptions used. A word or expression, in contrast to the image of objects or abstract themes, has a greater spectrum in perception, associations connected with its use and, accordingly, the reactions of the recipients. Therefore, it is the verbal element that is potentially at greater risk of creating unpredictably negative reactions on the part of consumers or people surrounding a person dressed in such clothes. We find this useful note and advice on the website of Aaryn West Design Studio, which develops prints and analyzes current trends. The designer advises either to apply typographic techniques in the design to prevent full reading of the displayed text or to choose a simple word or phrase that will be pleasant or neutral for everyone (West, 2014).

Despite the fact that such compositions do not often carry content loading, they attract the attention of people from the environment, their eyes somehow «cling» to words. Thus, the wearer of such fashionable clothes invites everyone around to communication and interaction, at least indirect or potential as a possible development of socio-cultural dialogue-exchange. 
It is important that the use of texts in the clothing decor in the context of their visual form alone does not reveal the person in its subjectivity and uniqueness. These are mass-produced clothing that, in all its appeal, is gradually becoming quite monotonous with the idea of design in its variety of variations. With such clothes, the person declares to the environment: «l am fashionable, I know on common trends and I follow them!».

The second group of typographic decor on clothing is formed on the principle of «content». In these projects, the message, the idea of the expression, matters because the test is crucial in a fashionable product. In fact, actual and modern such products are precisely due to typographic compositions because they are quite traditional in style or cut. In most cases, such decor is print on T-shirts or sweatshirts.

In the second group of clothing, typographic inscriptions occupy a visual compositional center (in front or on the back in the area of the upper third). They are a work of graphic design because they are usually laconic in artistic means, they show the depth of the idea. Compositional techniques in typography design were revealed earlier in the article on typography as a form of visual communication.

We note here that such compositions apply the scaling of letters, changes in their dimensional relations with each other, displacement relative to the baseline of the word, rotation around its axis of each letter and the whole word, doubling or tripling of letters, their partial removal, etc. (Udris-Borodavko, 2018). The font is selected by the designer to reveal the content. Preferably, modern fonts are used in order not to distract from the message itself.

In her article on the positioning of fashion innovations in the communicative space of contemporary culture, O. Shandrenko substantiates her opinion on the subordination of the human appearance to the functions of the legal and legislative mechanism and emphasizes that the way of such action becomes communicative and legal. The author concludes that fashion thus enables a person to assert his or her rights and obligations (Shandrenko, 2016).

In our opinion, manifestation by a person of his or her own point of view, which may be aimed at supporting or destructing, and even destroying certain social processes, takes on an overt form through verbal messaging on clothing. Among the many offers of printed T-shirts or hoodies, the consumer can find a formula that visualizes his or her inner experiences, thoughts, life conclusions, adherence to a certain lifestyle and life guidelines. The meaningful content of such statements can be divided into texts- provocations, that is, those that astonish the public with certain violations of ethical linguistic norms in society, and texts-appeals that are inherently social advertising, because they raise urgent social problems and adjust to their solution. Such topics today are, for example, maintaining the ecological balance, gender equality, justice (Fig. 4.3). 


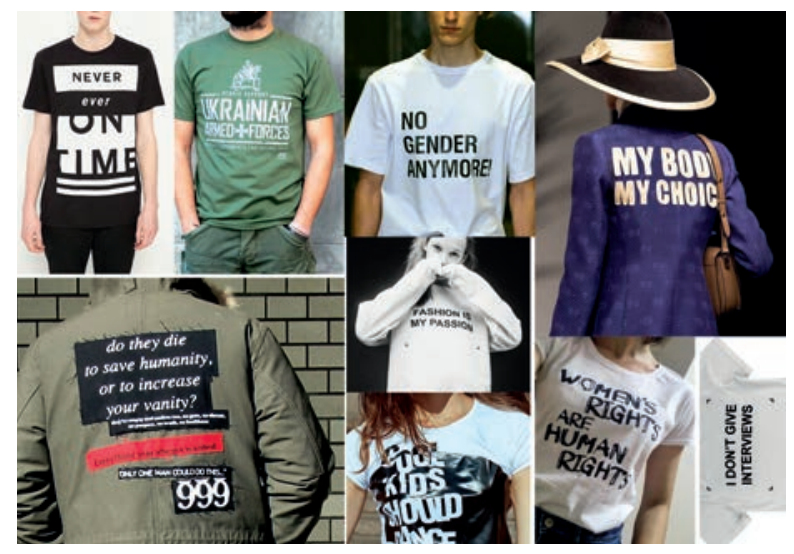

Fig. 4.3. Conceptual messages in typographic decor of clothes. Collections of 2017-2019 pp.

Рис. 4.3. Концептуальні повідомлення у типографічному декорі одягу. Колекції 2017-2019 рр.

It should be noted that clothes that use text messages with a specific social position refer mainly to street fashion, in the direction of «casual», urban sports style. These clothes are worn by representatives of such social groups as youth (by age criterion), independent, intellectual and hedonists (by social psychotype). Among the professional fields in which employees are allowed to use such clothing on a daily basis are the cultural professions (designers, musicians, photographers, and writers), PR and advertising communication, journalism, and programming. That is those people who value pluralism of thoughts and have the opportunity to express them openly with their outward appearance. Often, clothing with meaningful typographic content becomes part of a professional image.

It is also important to note, that decor of this type has deep cultural implications and often can be fully understood only in a particular society. This applies both to the language of the inscriptions and the dual meanings they carry. However, unlike the "formal" use of typography in fashion design, where it is better to adhere to neutral content, in «meaningful typography» the idea is precisely in the clear visualization of thoughts and positions. In the design of clothing with typographic inscriptions, the language of the country, where the collection is sold or English as a recognized international language is most commonly used.

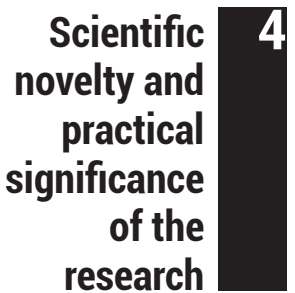

For the first time, the article summarizes the experience of typographic decor in clothing design 2013-2019 in terms of modernism and postmodernism concepts. Techniques, compositions' artistic features of each type are systematized. Moreover, the analysis was carried out in the form-content dichotomy system. It has been found that in the typographic elements, where the main purpose is the transmission of the content, mostly modernist approach is applied, and in those that perform the purely aesthetic function of forming creative decor with letters - postmodern. From the point of view of the communicative function of fashion, it has been found that well- 
known corporate brands use typography in clothing design often to support commercial communication, constant reminding of themselves among target groups. They are mainly created on the principle of «form». Content labels on T-shirts or sweatshirts are created by designers, mostly with individual activity, and they will have their own brand with limited collections. Through clothing decorated with typographic compositions, people can convey to the environment the messages of types: «l am creative» (postmodern compositions on the principle of «form»), «l am fashionable» (modernist compositions on the principle of «form»), «l am socially active» (Most often modernist compositions based on the principle of «content», but sometimes there are postmodern solutions).

Conclusions 5 Typographic decor as a trend in modern fashion adds to the clothes of relevance in the context of time matching because we live in a period of information flow. A person in a «typographic» outfit not only absorbs information flows. He or she as an object of communicative space becomes its source. The texts can be filled with straightforward unambiguous sensations and interpretations, inactive, or symbolic as visual-verbal simulacra of reality.

In any case, clothing with typographic decoration is a guarantee of attention from the environment. It tells about the creativity of the person wearing it, progressiveness, and intelligence, the presence of a public position or a philosophical understanding of life. Such clothes convey the meaning of what motivates and encourages people to direct or indirect communication.

\section{References}

Ambrose, G., \& Aono-Billson, N. (2019). Osnovy. Hrafichnyi dyzain 01: Pidkhid i mova [Basics. Graphic Design 01: Approach and Language] (T. Kryvoviaz, L. Baz, \& R. Dziuba, Trans.). Kyiv: ArtHuss [in Ukrainian].

Battista, A. (2013, March 28). New Typography with a Punk Twist: Mint Designs A/W 13. Retrieved from https://www.irenebrination.com/irenebrination_notes_on_a/2013/03/mint-designs-aw-13. html [in English].

Bets, S.M. (2014). Filosofsko-antropolohichnyi analiz funktsii mody [Philosophical and anthropological analysis of the fashion's functions]. Filosofiia i politolohiia $v$ konteksti suchasnoi kultury, 8, 16-20 [in Ukrainian].

Bringhurst, R. (2006). Osnovyi stilya v tipografike [The Elements of Typographic Style] (G. Severskaia, A. Semenova, \& S. Ponomarenko, Trans). Moscow: D. Aronov [in Russian].

Craig, J. \& Skala, I.K. (2018). Shrift i dizayn: Sovremennaya tipografika [Designing with Type: The Essential Guide to Typography] (5th ed.). St. Petersburg: Piter [in Russian].

Dahmoos, A. (2018). Emotional Perception of Typography Messages in Fashion Design. (Masters Thesis). Department of Graphic Design, Faculty of Architecture and Design Middle East University Amman, Jordan. Retrieved from https://meu.edu.jo/libraryTheses/5b55be3eabb62_1. pdf [in English]. 
Kim, S.-Y. (2009). Pattern and Aesthetic Characteristics of Modern Fashion using Typography. The Research Journal of the Costume Culture, 17(2), 283-295 [in English].

Knight, C., \& Glaser, J. (2012, April 13). When Typography Speaks Louder Than Words. Retrieved from https://www.smashingmagazine.com/2012/04/when-typography-speaks-louder-thanwords/ [in English].

Murashko, M. (2016). Proektno-khudozhnii instrumentarii moushn-dyzainu (na prykladi reklamnoho rolyka) [Design and art tools of motion design (of the case of the advertising)]. (PhD Dissertation). Kharkiv state academy of design and arts, Kharkiv [in Ukrainian].

Nester, L. (2016). Komunikatyvnist mody u noveli Hotfrida Kellera "Odiah tvoryt liudei" ("Kleider machen leute") [The communicative fashion in Gottfried Keller's novel "Clothes make people" ("Kleider machen leute")]. Visnyk of the Lviv University. Series Foreign Languages, 23, pp. 183-188 [in Ukrainian].

Opaliev, M., \& Savvina, K. (2014). Etapy rozvytku animovanoi typohrafiky v moushn-dyzaini [Stages of animated typography development in motion design]. Bulletin of Kharkiv state academy of design and arts, 8, 77-80 [in Ukrainian].

Papanikolaou, N. (2014, September 27). Typography is an all-time classic fashion trend. This is why. Retrieved from http://www.typeroom.eu/article/typography-all-time-classic-fashion-trendwhy [in English].

Shandrenko, O.M. (2012). Vyiavlennia sutnosti mody yak komunikatyvnoho yavyshcha kultury [Revealing the essence of fashion as a communicative phenomenon of culture]. Bulletin of Kharkiv state academy of design and arts, 8, 132-135 [in Ukrainian].

Shandrenko, O.M. (2016). Pozytsionuvannia modnykh innovatsii v komunikatyvnomu prostori suchasnoi kultury [The positioning of fashion innovations in the communicative space of contemporary culture]. International Scientific Journal, 2, 41-46 [in Ukrainian].

Shevchenko, V. (2014). Stanovlennia naukovoi dumky shchodo movy vizualnoi komunikatsii [Formation of scientific thought in the language of visual communication]. Bulletin of the Book Chamber, 9, 1-3 [in Ukrainian].

Skender, L. (2015). Typography In Fashion Design. Sarajevo [in English].

Trésor. (2012, October 27). Typography in Fashion. Retrieved from https://tresordesign. wordpress.com/2012/10/27/typography-in-fashion/ [in English].

Trésor. (2014, February 1). Typography trend in S/S 2014 collections. Retrieved from https:// tresordesign.wordpress.com/2014/02/01/typography-trend-in-ss-2014-collections/ [in English].

Udris-Borodavko, N. (2018). Typohrafiia yak forma vizualnoi komunikatsii. [Typography as a form of visual communication]. Topical problems of History, Theory and Practice of Artistic Culture, 40, 227-236 [in Ukrainian].

Unger, T. (2017, August 11). Wearing Your Voice with Fashion and Typography. Retrieved from http://alfalfastudio.com/2017/08/11/fashion-and-typography/ [in English].

West, A. (2014, 15 December). Spring 2015 Runway Trends: WordSmith. Retrieved from http:// www.aarynwest.com/tag/typography [in English]. 